\title{
THE ROLE OF MICROFINANCE IN RIGHT-BASED APPROACH TO FOOD IN AFRICA
}

\author{
Mago Stephen, Mutami Cephas, Lecturers \\ Great Zimbabwe University, Masvingo, Zimbabwe \\ E-mail: stepmago@gmail.com, cmutami@gmail.com
}

\begin{abstract}
The purpose of this paper is to explore the role of microfinance to food security using the lens of the Right-Based Approach to food. The paper adopts a qualitative research methodology, following an exploratory research design. The research findings show that microfinance has a positive contribution towards rights to food and food security. However, in other African contexts, microfinance worsening the status of the poor. It was thus established that proper management of microfinance programs is likely to bring more benefits than problems. Making the 'right to food' and the 'right to credit' aspects of human rights will strengthen the productive systems of food to ensure sustainable supplies for effective food security mechanisms. The paper recommends that the linkage between microfinance and food rights be escalated to policy level discussions. Policies that promote a combination of the two rights need to be developed.
\end{abstract}

\section{KEY WORDS}

Microfinance; Rights-based approach; Food security; Right to food; Right to credit.

The right to food is an urgent concern in Africa and the world over. Hunger, starvation, undernourishment, malnutrition, diseases and poverty are the associates of the failure by individuals and households to have food supplies. The world has gone through the tough food crises and the heaviest burden has always been on the poor people. The poor are vulnerable to a number of shocks, they are voiceless (Narayan, 2002) and they do not have enough assets for their survival. Their coping strategies are distracted by a number of environmental and manmade 'noises' hence the need for an urgent attention to address the notion of rights to food. Elimination of hunger through the rights to food is an urgent priority (Ziegler, 2006) which is one of the United Nations' Eight Millennium Development Goals (MDGs). People who do not have access to food always face the challenges of life. Underdevelopment of human brain cells, vulnerability to disease, physical deformities (before and/or after birth), blindness and other related effects are some of the effects of hunger on human development. As Martins and Yablonski (2011:10) outline, «underdevelopment during children's critical years causes indelible damage». Thus, lack of access to food by children destroys the future generation. This present article is not arguing for food aid. It wishes to go beyond and look at food security with special focus at a 'higher level concept' of rights to food.

In 2010, the Food and Agricultural Organization (FAO) reported that about 925 million people were undernourished and hungry. Of the 925 million hungry people, the sub-Saharan Africa contributed 239 million after Asia and the Pacific that contributed 578 million. According to FAO's The State of Food Insecurity in the World Report of 2010, the number of people who are undernourished is still at unacceptable levels despite a decline from 2009. Strategies still need to be put in place to ensure achievement of Millennium Development Goal 1 that aims at halving the number of hungry people by 2015 . Hungry people have no access to enough food items; hence they do not have rights to food. Figure 1 below shows the world's number of undernourished people from 1969-71 to 2010 span.

In 2012, the World Food Programme (WFP) statistics stated that nearly one (1) billion people in the world go to bed hungry each night. These statistics enlighten us about the urgency for implementing the right to food in Africa and the world over. It has become an urgent concern since people may be denied access to food thus leading to hunger, starvation and malnutrition. These are strong drivers of poverty which results to deprivation, marginalization and suffering of the people. The International Covenant on Economic, Social 
and Cultural Rights has included «rights to food» in its covenants so as to protect people from the effects of food inaccessibility.

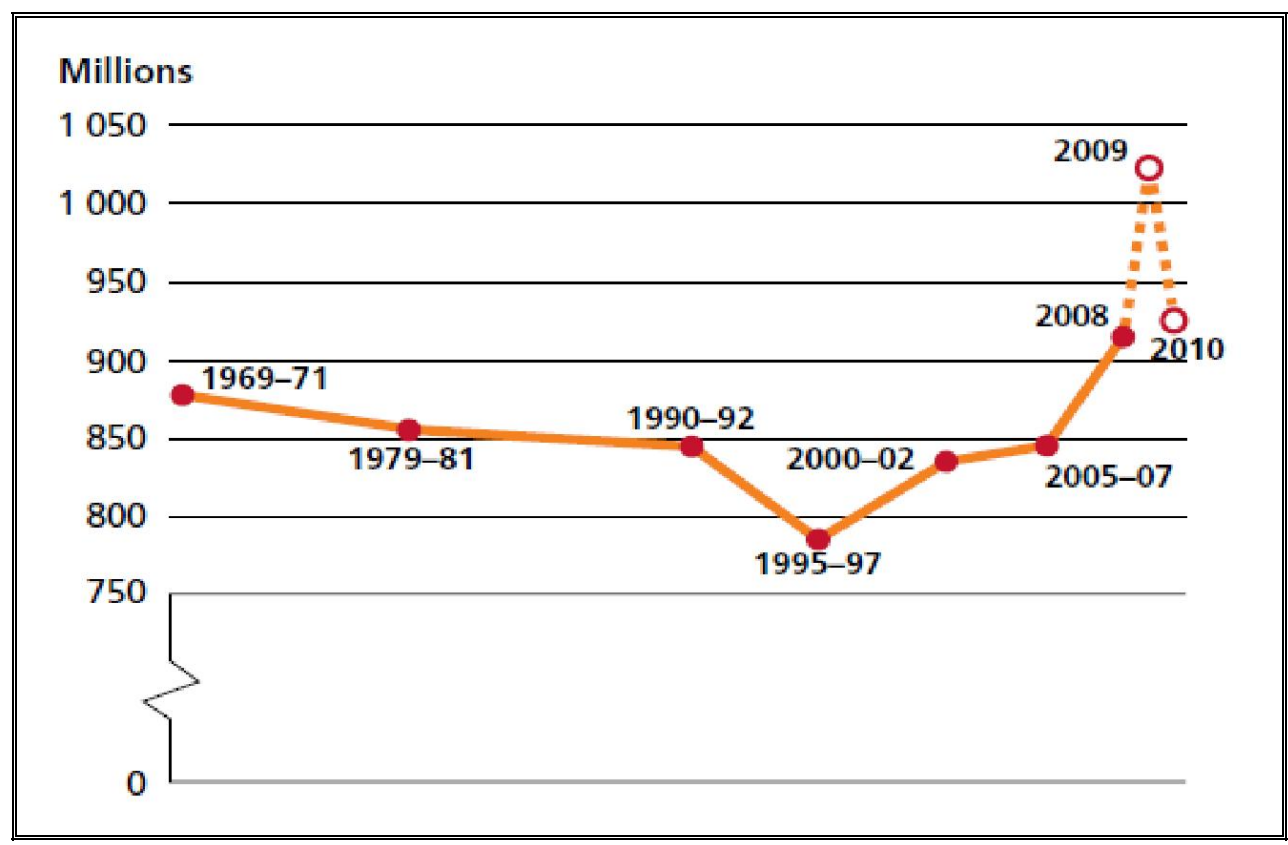

Figure 1 - Number of Undernourished People in the World, 1969-71 to 2010 Source: FAO (2010:9)

The African continent is the world's second largest and second most populous after Asia. It is endowed with plenty of resources (both human and natural), but it remains the world's most underdeveloped and poorest. According to Getu (2001:165) «... despite its natural and human resources, Africa is the poorest continent in the world. Thirty of the world's forty poorest countries are in Africa and more than 50 percent of the continent's 600 million people suffer from absolute poverty». Largely, the problems of underdevelopment and poverty are attributed to the hangovers of the slave trade, colonialism, failed central planning, corrupt governments, human right violations, conflict and war. The problems have caused socio-economic and political nightmares within the African states. Because of the multidimensionality of the problems in Africa, we need a number of strategies to address them. Since poverty and underdevelopment are multidimensional and interconnected with social, economic and political dimensions hence there is need for different strategies for addressing the problems. We cannot promise a single guaranteed approach for addressing poverty and underdevelopment. Food insecurity also emerges from poverty and underdevelopment. This could also be an outcome of lack of rights to food or inaccessibility of finance by the poor. Microfinance is believed to be one of the strategies that can be used in the African context to ensure that the right to food is achieved. Thus a link or connection between right to food and microfinance needs to be established. This article therefore questions whether there is a link between the right to food and microfinance in the African context.

Microfinance and Rights to Food. The question is whether there is a link between microfinance and rights to food. 'Microfinance' refers to the issuing of small (micro) loans to the economically active poor people with a follow-up of services such as training and other forms of support. This makes it functionally and conceptually different from 'microcredit' which realizes that credit is the only missing link in the finance-related poverty reduction interventions. This article aims to trace the link that exists between microfinance and food rights. What can microfinance do to promote food rights? What could be the implications of microfinance programmes on food rights? Are people with access to microfinance likely to have the rights to food? The following section conceptualizes the main concepts discussed herewith. 
Microfinance and the Question of Size. Schumacher (1973), in the book "Small is Beautiful: A study of Economics as if People Mattered» outlined the "Question of Size» by stating that «...in the beginning was the family; then families got together and formed tribes; then a number of tribes formed a nation; then a number of nations formed a 'Union' or 'United States' of this or that, finally we could look forward to a single World government» (p52). Microfinance has always been questioned because of the 'smallness' of the loans passed on to the poor people. Given Schmacher's thoughts about small things, the beauty is that there is a potential for growth for their realization of bigger results in the future. Small is beautiful and dynamites come in small packs. Microfinance could be a 'dynamite' that looks small, insignificant and useless yet effective in future for the achievement of food rights among the marginalized and disadvantaged.

Microfinance, the provision of small loans to the poor, has attracted worldwide attention since the 1970s when Muhammad Yunus (a Nobel Prize winner) realized its potential in his Bangladesh experiments. Started after realizing that classroom economic models were not helping the poor to move out of poverty, Yunus started giving out small amounts of money to the poor from his pocket. The experiments proved to be worthwhile because they led to social transformation through the alleviation of poverty among the participants. Today, the microfinance sector points to the Grameen Bank \& Bangladesh Rural Advancement Committee (BRAC) [Bangladesh], ACCION [The US], K-REP [Kenya] as success stories in driving the microfinance revolution, as Robinson (2001) calls it. Farrar (2008:1) states that «Muhammad Yunus of the Grameen Bank says microfinance and microcredit programs can literally end world poverty». World poverty seems to be perpetuated by the lack of right to food by the majority of people.

The Right to Food-Microfinance Nexus. Amartya Sen, in one of his seminal works, Poverty and Famines (1981) states that «Starvation is the characteristic of some people not having enough to eat. It is not the characteristic of there being not enough to eat. While the latter can be a cause of the former, it is but of many possible causes» (cited in Ahluwalia, 2004 p7). Sen's statement indicates to us that the availability of food may not necessarily guarantee access to food. Sen further argues that hunger is a product of poverty, marginalization and disempowerment. The hungry are those who have no access to adequate food. People need to have both physical and economic capability to access food, thus food becomes a 'human right' for all humanity. This is why the right to food has gained entry into a number of international covenants so as to protect people against starvation.

Zeigler (2006:4), the UN Special Rapporteur, before De Schutter, asserted that «The right to food is a human right». The right to food goes beyond food security. Whilst the world is producing enough food for everybody (FAO, 2010 and Action aid, 2012), about one in every six people goes, on daily basis, to bed hungry. FAO reinforces this assertion by stating that, "The root cause of hunger and malnutrition is not a lack of food but a lack of access to available food" (as cited in UNHR and FAO, n.d p4). This opens a window for us to see that the question of rights to food or food rights is vital to answering the questions of poverty and vulnerability. Access to food influences the right to food. The UN Special Rapporteur defines the right to food as;

The right to have regular, permanent and free access, either directly or by means of financial purchases, to quantitatively and qualitatively adequate and sufficient food corresponding to the cultural traditions of the people to which the consumer belongs, and which ensures a physical and mental, individual and collective, fulfilling and dignified life free of fear (Committee on Economic, Social and Cultural Rights, 1999:3).

The Committee on Economic, Social and Cultural Rights defines the right to food as;

The right to adequate food is realized when every man, woman and child, alone or in community with others, has physical and economic access at all times to adequate food or means for its procurement. The core content of the right to adequate food implies (...) the availability of food in a quantity and quality sufficient to satisfy the dietary needs of individuals, free from adverse substances, and acceptable within a given culture (and) the accessibility of such food in ways that are sustainable and that do not interfere with the enjoyment of other human rights (Golay, 2009:11-12). 


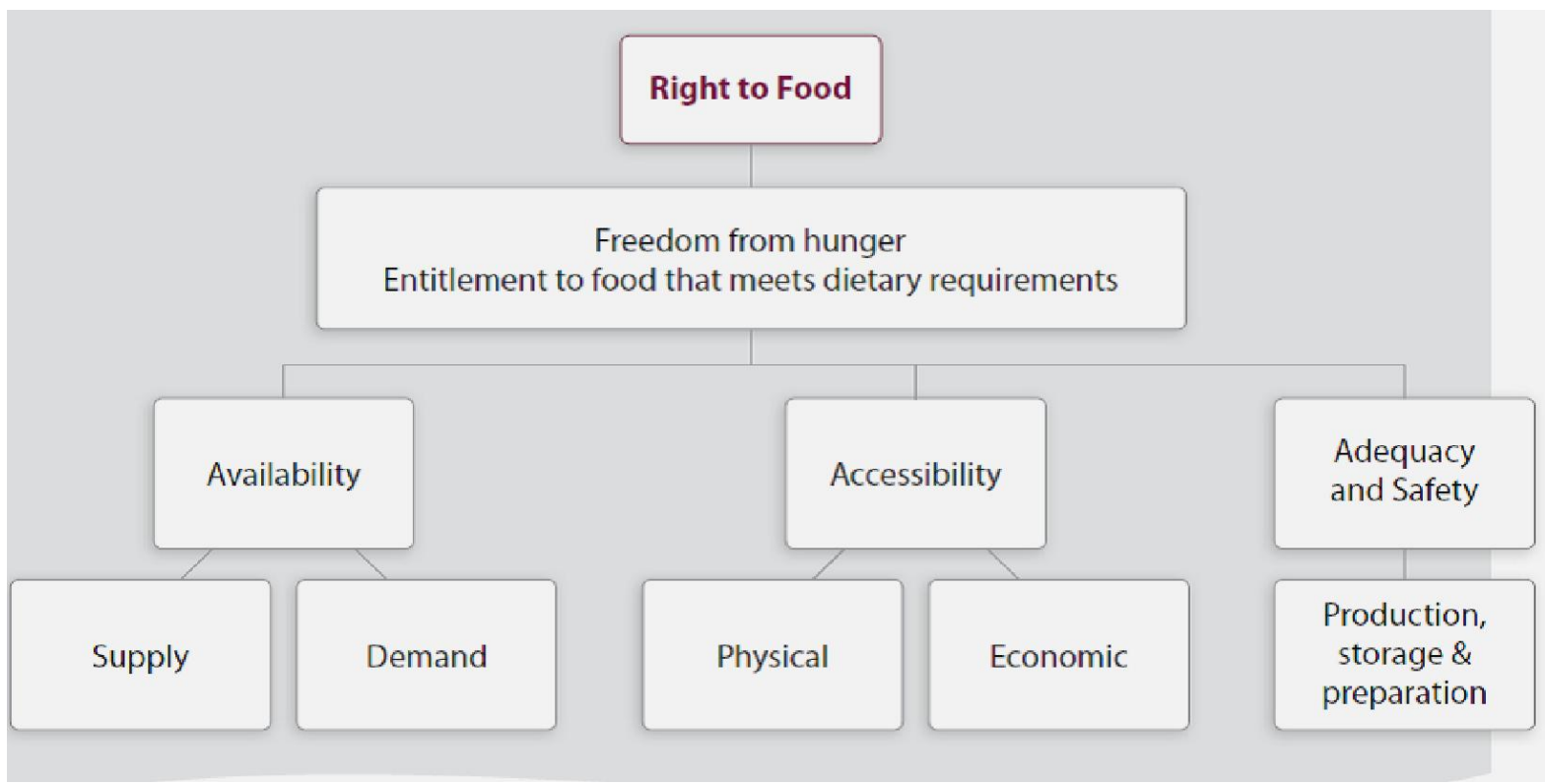

Figure 2 - Right to Food Schemata Source: $F A O$ (2008:5)

In figure 2, it can be clearly seen that the right to food means that the people must be free from hunger and have entitlement to adequate dietary requirements. This is enhanced through availability, accessibility, adequacy and safety of food.

Availability refers to the forces of demand and supply. It means that food should be present through production processes and effective use of resources (natural, financial, human and social). Economics are always comfortable with a condition of equilibrium or state of rest where demand is equal to supply. When the food available (supply) is equal to the food being demanded by the people (effective demand), then people are away and free from hunger, thus they have the right to food. Shortages are always uncomfortable because they create excess demand hence generating food crises. The food crises of the 1970s, for instance pushed the prices of food items upwards, making it unreachable by the poor people. Once food becomes unavailable and unreachable, the people become food insecure hence they fail to have the right to food. Many people are food insecure even in economies that are performing very well. For example Drugmand (2011:1) states that «South Africa is home to 12 million food insecure people, 70 percent of whom are in rural areas». If South Africa has such figures, what is the situation in Zimbabwe, Mozambique and Zambia? The blame is shifted by De Schutter to an exclusive food system in South Africa and other countries. During his visit to South Africa, he encouraged the government to adopt an inclusive food system so as to develop a food economy that benefits the majority of the people. The poor are expected to benefit from such a system since it advocates for exclusivity hence the marginalized are catered for and they have access to food and the rights to access it. Microfinance for the poor is known to improve their productivity hence making food to be available for consumption by all groups of society.

Accessibility refers to both physical and economic means that make people to be able to get food. Physical accessibility implies that food is within the reach of all groups including the disabled, women and children. People located in the rural remote areas must also have access to food. As indicated earlier, Sen's approach argues that lack of access to food is responsible for the hunger that is in the world. He argues that people are not hungry because the world is producing little food, but the problem is woven around access to food. Such could be made possible through the improvement of road and communication facilities and also the development of markets. In addition, victims of natural disasters (such as Tsunami) and conflict should not be denied access to food.

And adequacy and safety talk about the production process, storage and preparation of food. Adequacy also means that the food must be in a position to meet recommended dietary 
needs. For example, food that is meant for children should contain appropriate levels of nutrients that promote physical and mental development. Children's foods that lack such nutrients are considered inadequate hence they do not promote the right to food. Another example is with the foods that have adverse substances. These include foods causing obesity. FAO (2010:3) notes that «Adequate food should also be culturally acceptable». So, food that violates religious or cultural values is considered inadequate. All the three elements should be present for people to have the 'right to food'. In the absence of the aforesaid elements, right to food becomes non-existent or remains a pipe dream.

The right to food can also be established from a justice perspective. Rawls (19711999), in his book on Theory of Justice outlines two principle of justice. His second principle is of interest in this context. He suggests that social and economic inequalities need to be rearranged so that the least-advantaged members of each and every society are made to benefit. Socio-economic inequalities are a product of social exclusion, marginalization and inconsiderate distribution of resources. Microfinance is one of the critical resources needed by all segments of society. The poor are often referred to as the 'unbanked'. Conventional wisdom argues that they are carriers of risk such that extending credit to them becomes suicidal. Yunus' argumentation is informed by the need to use credit as an efficient instrument to achieve the right to equal opportunities. Such an empowerment will help to reduce poverty. In his own words Yunus $(2006,2007)$ states that «nobody can get the right to food, right to shelter, right to education and health until he creates his or her own income strength». These rights are connected and they seem to be driven by the right to credit. Rawls (1971/1999:42) further strengthens the argument by saying that the access to credit falls within the global justice framework. Credit then becomes a global right and the same with the right to food. As stated earlier, the right to food has gained entry into the international covenants that promulgate human rights.

The provision of financial resources to the poor has an impact of improving their economic conditions. This will in turn lead to better access to food hence improving the overall food security. An illustration in figure 3 below demonstrates a simplified causal chain of microfinance and the right to food. Food production is an important component of food availability, accessibility and adequacy. Small-scale farmers play a significant role in the production of food. For example, the International Institute for Environment and Development's (2012) blog states that Brazil's Zero Hunger program has received immense contribution from small-scale farmers. Farmers who have access to microfinance have an opportunity to improve their production. Improved productivity makes them, and the communities to have access to economically affordable food items. On the other hand, lack of access to financial resources will affect productivity negatively. Reduced food productivity will also lead to poor food access hence the right to food is violated. Such violation creates a vicious cycle of poverty and the poor hardly climb out of poverty.

The CGAP, in 2008, lamented that 'the worldwide number of poor people that have access to credit is nowhere near the market potential. Given that almost 3 billion people live on less than two dollars a day, clearly the battle to bring financial access to as many people as possible is a very long way from being won'(Farrar, 2008:8).

The concern registers the perennial need for access to credit by the poor people. Access to credit translates to physical and economic access to food hence improving the food rights position of the poor.

Access to microfinance helps poor people to accumulate assets. Assets accumulation is one of the buffers that can be used to smooth fluctuations in consumption. Asset holding further helps people to use them as collateral hence increasing the access to more credit. However, current experiences and research have shown that microfinance can also be accessed using group peer pressure methodology. In this regard social bonding or social capital is used as collateral (Meinzen-Dick and Di Gregorio, 2004). Property rights also work as buffer against risk. In the event of shocks, livelihoods of vulnerable groups are negatively affected. If people have property rights, they can fall back on their assets hence improving their coping mechanisms. 


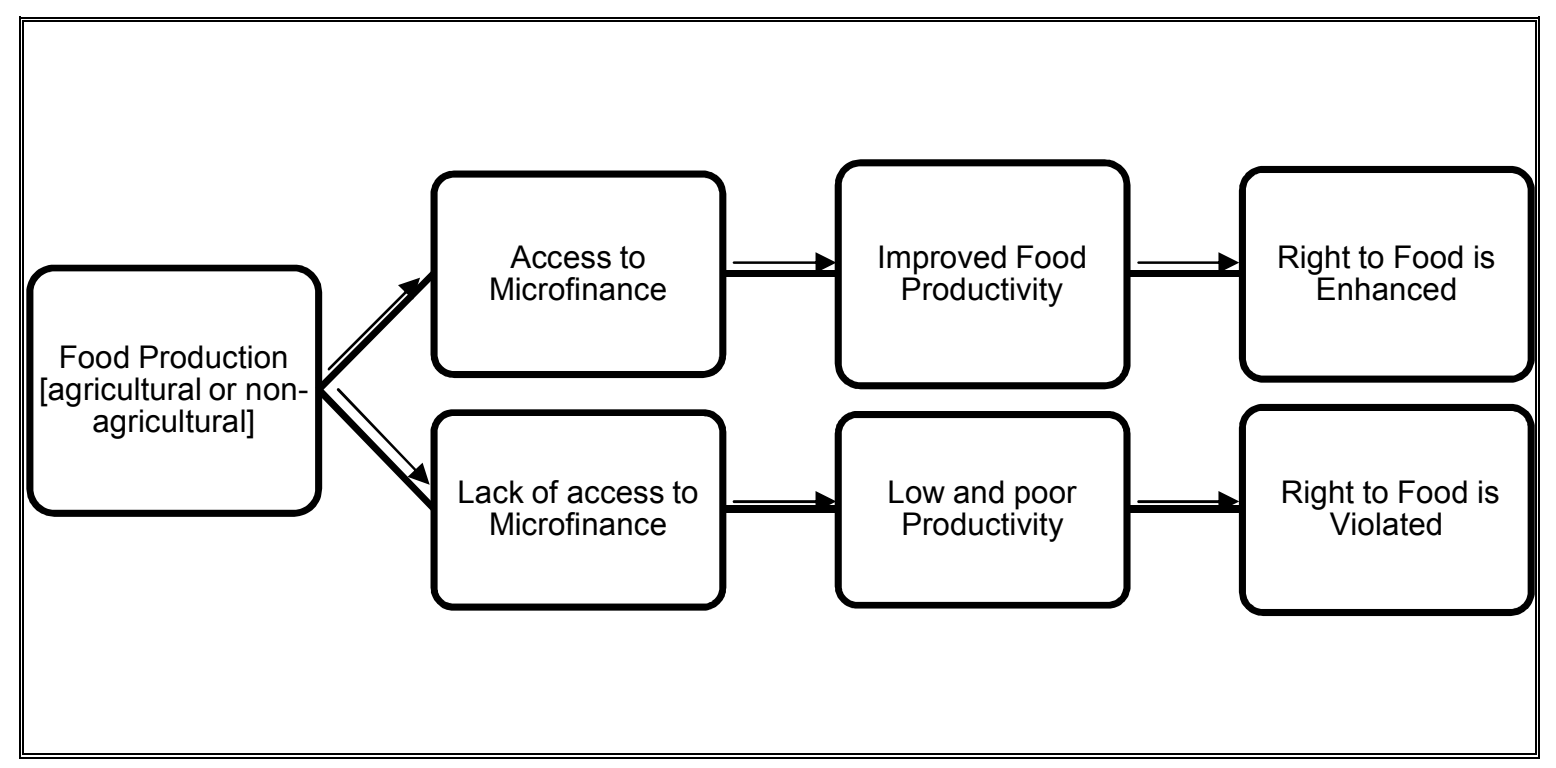

Figure 3 - A Simple Causal Chain of Microfinance on Right to Food Source: Field work, 2014

Credit as a Right. Many businesses and agricultural actors have expressed that lack of access to credit is the main constraint for all productive efforts. It is a fact that many people in the world have no access to credit. The Center for Financial Inclusion (2012:1) states that «more than 2 billion people worldwide lack access to basic financial services». Hudon (2004:3) states that «credit is central to the welfare of many citizens in high and low-income countries». This is a clear sign that credit requirements transcend country boundaries. Yunus, the 2006 Peace Nobel Prize Winner, argues that it is imperative that credit be considered as a human right. Rights have become central to discourses on development and social transformation. Amartya Sen, a renowned figure and theoretician of famine (Rahim, 2011) argues that poverty results from the lack of freedom. Lack of freedom, according to Yunus is perpetuated by lack of access to credit. Furthermore, Sen (1999) and Pogge (2002) argue that that microfinance plays a significant role in poverty eradication. Financial exclusion is therefore a negative force that worsens unfairness and inequalities in the distribution of resources. Formal financial institutions are either unwilling or unable to provide finance to the poor people especially those involved in agriculture. This is preponderant in developing countries. This condition creates imperfect markets that inhibit access to finance hence incapacitating people to have access to opportunities such as food, shelter, clothing, transport and many others. This article therefore argues that making credit a human right empowers the poor to fight hunger, malnutrition and starvation. According to Hudon (2004:7), "A right to credit is one instrument to accomplish this common good», referring to poverty reduction. It is however important to note that for credit to be beneficial, it should be used for productive activities. Thus extreme outcomes of overburdened borrowers and destitution are avoided. Rather, access to food is enhanced and the right to food is promoted. Sen's "goalright system» suggests that the right to credit should not be taken blindly. Rather, there is needed to take into account important elements to ensure positive outcomes and avoid or prevent negative ones. Microfinance On the other hand, people need to have the right to food. These dual rights augment each other. The right to finance strengthens the right to food through access, availability and affordability.

The Rights-Based Approach. When two 'rights' meet "The Right to Food» and "The Right to Credit» what will be the implications? The theoretical underpinning is the RightsBased Approach that ensures that meaningful and systematic inclusion and empowerment of the poor. FAO (n.d:1) asserts that «The right-based approach to food security holds that people have a fundamental right to be free from hunger. It considers the beneficiaries of development not merely as passive recipients, but as active stakeholders». Further, it posits 
that free food does not constitute the right to food. People should be emancipated from depending on free food handouts and have the capability to feed themselves so that they do not become 'food slaves'. More importantly, the right to food, which involves the freedom to eat decently and sustainably (Dowler, 2011) needs to be upheld. Food handouts create «dependency, 'poverty traps', and demeaning rather than motivating solutions» (Dowler, 2011:3). They also cause poor people to «...eat diets which stave off hunger but don't serve long-term health» (Dowler, 2011:3). Using the lens of right to food approach (Rahim, 2011) allows this article to go beyond the notion of food security. Making food a human right will make the world's poor to have sustainable access to food.

Lack of finance is seen as one of the damaging obstacles to the notion of food rights. It is therefore important to establish the link between microfinance and right to food. The paradox remains that the world is rich with resources but the people are poor. Ziegler(2012,p1), in the Right to Food blog, laments that «In a world overflowing with riches, it is an outrageous scandal that almost 900 million people suffer from hunger and malnutrition and that every year over 6 million children die of starvation and related causes. We must take urgent action now. This is my ongoing fight for the right to food».

According to De Schutter (2010:7), «Laws alone are not sufficient to realize the right to food in a country». Since economic factors such as microfinance also drive the right to food, it is then imperative to bring them into the picture. Microfinance, a financial right for the poor, can be brought at the centre of development thinking so as to influence the realisation of rights to food among the poor. According to Falk (n.d.), «The Right to Food implies access to productive resources and an environment, which enables people to feed themselves in dignity». Thus the need the need of microfinance cannot be overemphasised. The provision of relieve food, though appreciated, does not constitute dignified consumption. A growing number of literature shows that food parcels given to the poor have made them to lose their dignity due to 'aid dependency' (see for example Chakravarti, 2005; Harvey and Linda, 2005; Lautze and Hammock 1996).

Economists categorise productive resources into land, labour, capital and enterprise. This applies to all levels where resources need to be optimally used for the attainment of maximum possible satisfaction. It is commonplace believe that capital plays a central role since it can be used to acquire the other three factors of production. For the poor people and their businesses, they need capital in form of microfinance. Thus productivity is improved by the availability and access to financial resources. As a result, access to microfinance allows the poor people to improve their capabilities to supply food. Small-scale farmers are in a position to boost their production thus promoting their ability to feed themselves, their families and communities with dignity. They are empowered to make their production-related decisions hence they are emancipated from hunger, starvation, exclusion and marginalisation. What we need in Africa are well crafted microfinance programmes. These have a potential of being empowering and generate sustainable improvements in household poverty reduction and increases in income. This assertion is not giving glory to the moneymetric measures of poverty that have faced criticisms.

De Schutter (the current United Nations Special Rapporteur On The Right To Food) in 2010 stated that;

The right to food is not primarily the right to be fed after an emergency. It is the right, for all, to have legal frameworks and strategies in place that further the realization of the right to adequate food, as a human right recognized under international law. By directing the adoption of these policies, the right to food is a compass to ensure that policies are geared towards alleviating hunger and malnutrition (2010:1).

De Schutter affirmed that ua rights-based approach is crucial in attaining global food security, particularly in developing nations» (Arnow, 2012). He further states that «described the potential of a rights-based approach in replacing the current supply-and-demand model. This approach is not just about availability, but requires that we pay attention to both food accessibility and adequacy» (Arnow, 2012). In his own words De Schutter said, "I believe that accountability, participation, and empowerment are absolutely key ingredients in the success of food security strategies» (Spivack, 2012 p.1). He further states that «the idea of a 
'right to food' is essential in transforming our broken food system into a sustainable, ethical institution».

Gender mainstreaming. Women and children are part of the vulnerable groups in societies. Their plight is worsened by their limited access to resources such as land, and credit. In most paternalistic societies, especially in Africa, they have no right to land so they lack collateral security that guarantees them access to financial resources from formal financial institutions. With this backdrop, microfinance has been hailed as one strategy for involving women in economic activities.

A large body of literature shows that more women than men are involved in microfinance activities have more women than men, ranging from $70 \%$ to $95 \%$ (see Armenderiz de Aghionand Morduch 2005; Robinson, 2001 and Khandker, 1998). A number of arguments have been advanced with some arguing that women are comfortable in dealing with small amounts of money while men want to deal with bigger amounts (CARE, 2007; Khandker, 1998). However, other authors argue that the microfinance programmes tend to select women who look after the families while men are in the city or in the diaspora (Khandker, 1998). This is common in Africa where men joined the 'diaspora bandwagon' in search for greener pastures. For example in Zimbabwe, a large number of men left the country to look for opportunities in neighboring and abroad countries. It is common knowledge that Zimbabweans emigrated to South Africa, Botswana, United Kingdom, Canada, United States of America, Australia and New Zealand during the crisis decade.

Armenderiz de Aghion and Morduch (2005) argue that when small financial resources are directed to women household welfare tends to increase because they use the money in the home. They further argue that men tend to spend the money on leisure than supplying the household basics. Further to this, Pitt and Khandker's 1996 and 1998 studies in Bangladesh established that the number of school going girls increased when women were given loans than when given to men (Khandker, 1998). Further, empirical findings by Mago (2010) show that many women (82\%) participate in microfinance hence confirming the assertions from previous literature.

African Context. Internationally, the three continents with serious food-related problems are Africa, Asia and Latin America. The problems include food shortages, infrastructural nightmares, malnutrition, food maldistribution, food inaccessibility and poor production. Such conditions have been exacerbated by climate changes. More to that access to food by the poor is being suppressed by the lack of rights to food. The notion of rights to food suffers from lack of support and recognition in most African countries. Academics, economists, sociologist, development experts and experts from many fields agree that Africa is the most resourced but the poorest continent in the world. Resources are abundant in form of human, natural and social. With regards to human resources, it enjoys the youngest labor force. «Demographic dividend» is claimed to be high in Africa as compared with the developed counterparts that have ageing population. The population in Africa is energetic and has high productive potentials. Natural resources are also abundant. These include minerals (diamonds, oil, platinum....gold, tin, copper, emerald etc), water, the African sun, rich agricultural soils and so on. Social capital is also 'awash' because of African social networks that are embedded in communities and extended family arrangements. These are complex arrangements but they promote solidarity and other connections. Despite such richness in resources, the continent has the poorest people.

It is also important to note that some countries in Africa are making progress toward promoting the notion of right to food. In an effort to synchronize the international food rights efforts to that national endevaours, a number of African countries have included right to food as a human right in their conventions. For example, in 1996 South Africa included the right to food in its constitution; in 2010 Malawi adopted the Right to Food Bill and in the same year Mozambique drafted the Right to Adequate Food Bill (De Schutter, 2010). The strengthening of rights to food could also have a positive contribution towards the development small-scale agriculture.

Small-scale agriculture has an immense contribution to food productivity in the African economies. The African state is therefore obligated to support small-scale agriculture so that 
people are in a position to feed themselves. As indicated earlier, the right to food does not entail receiving food handouts from the state and non-governmental organizations (NGOs). Though these are important in times of emergencies such as natural calamities and wars, they should not be considered a prime supply of food for the people. What small-scale farmers need is the support to have their own food supplies, hence achieving dignity to the access to food. Rahim (2011:8), in his article Rights to Food with a Human Face in the Global South reminds us that «Small-scale farming could bring about substantial benefits to a country and result in a reduction of poverty». This is a pointer to us that small-scale agriculture needs profound agro-changes and these can be achieved by providing finance to the small-scale farmers. Food productivity has the desired potential to keep people far away from hunger and starvation.

Access to finance by small-scale farmers enables them to acquire credit for the purchase of farming equipment and agricultural inputs such as seeds, fertilizers and herbicides. Accumulation of savings is also enhanced. The accumulation of savings increases their investment in both farm and non-farm activities. Farm productivity is also enhanced since they will be in a position to acquire inputs and farm equipment. This article advances that capital injection via microfinance will improve productivity hence food security is promoted. The small-scale farmers can supply their families with food rather than depending on food hand-outs. Agricultural production credit is an important factor income for both farm and non-farm activities. However, this article focuses on agricultural production which has a direct impact on food production, food security and hence rights to food. Improved agricultural productivity has an impact of improving the disposable income for consumption and investment hence encouraging local economic development and poverty reduction. Empirical studies in some African countries will help to give a clear picture of the linkage between microfinance and right to food.

Akanni (2007), in a study of small-scale poultry famers in Western Nigeria established that microfinance improves the productivity of small-scale poultry farmers. The study found out that farmers with access to credit have an upper hand when it comes to productivity. It was then concluded and recommended that small-scale farmers need microfinance so as to boost their production thus improving the food security status and allowing farmers to have descent food supplies. Policies meant to promote agricultural and rural development should aim to strengthen small-scale farmers and diminish the control of the powerful.

Concluding Remarks and Implications. The forgoing discussion gives us a clue that microfinance promotes the rights to food. This article has made attempts to conceptualize the two rights- 'right to food' and 'the right to credit' (microfinance). Making these two aspects human rights will strengthen the productive systems of food to ensure sustainable supplies for effective food security mechanisms. Right to food has gained entry into the international human right conventions and the national constitutional laws. This is encouraging because many countries in the world are adopting strategies meant to promote food rights. For example, countries like India, Guatemala, Brazil, Ecuador, Nepal, Nicaragua, South Africa, Malawi and Mozambique have made significant progress towards adopting the rights-based approach to food security. They have developed a number of policy instruments that recognize the notion of «The rights to Food» for achievement of dignified access to food by poor people. Small-scale farmers have a profound contribution in the production of food in developing countries including African countries. Their major constraint is the availability of resources for agriculture. They lack land resources such that they rely on tiny pieces of land that do not have title deeds. Lack of title deeds makes it worse because they cannot use the land as collateral security to access loans from banks. Their land becomes 'dead capital' as was coined by the Italian economist Henardo de Soto. Land only becomes a double benefit if the holders have title deeds to use as collateral security to access loans from financial institutions and at the same time use it for agricultural production. Access to loans will boost agricultural productivity since the farmers can purchase agricultural equipment and inputs. Consequently, improved productivity will make farmers and the communities to have access to adequate food hence they have the 'right to food'. This article therefore recommends that microfinance programmes should be used to support small-scale agricultural productivity 
thus strengthening the 'right to food' especially among the poor segments of society. The linkage between microfinance and food rights needs to be escalated to policy level discussions. African states need to facilitate (with fast tracking) the acceptance and inclusion of 'the right to food' into national policy and legal instruments for dignified access to food by African citizens.

\section{REFERENCES}

1. Action aid (2012) Action for change: Action Aid UK strategy 2012-2017. www.actionaid.org.uk

2. Ahluwalia, P. 2004 , The Implementation Of The Right To Food At The National Level: A Critical Examination Of The Indian Campaign On the Right To Food As An Effective Perationalization Of Article 11 Of ICESCR. Center For Human Rights And Global Justice Working Paper Economic, Social And Cultural Rights Series Number 8, 2004.New York.

3. Akanni, K.A., 2007. Effect of Microfinance in Small Scale Poultry Business. In SouthWestern Nigeria. Journal of Food and Agriculture 19(2), 38-47.

4. Armendariz de Aghion B and Morduch J. (2005): The Economics of Microfinance, Massachusetts Institute of Technology, London

5. Arnow Olivia. 2012. De Schutter Highlights the Importance of a Rights-Based Approach to Food Security. http://blogs.worldwatch.org/nourishingtheplanet/de-schutter-highlightsthe-importance-of-a-rights-based-approach-to-food-security/. 14 August 2012.

6. CARE. 2007. Enhancing poor Households' Economy and Empowering the Marginalized: Implementation on Internal savings and Lending (Microfinance) Intervention. CARE's Microfinance Programme Document. Zimbabwe: CARE.

7. Chakravarti Ashok. (2005): Aid, Institutions and Development: New approaches to Growth, Governance and Poverty Edward Elgar Publishing, Inc. UK.

8. Council of the United Nations. Report Symbol: E/CN.4/2006/44/Add.1. http://ap.ohchr.org/documents/dpage_e.aspx?m=101

9. Dowler, 2011. Ensuring decent food for all...? In Liz Barling, Robin Dru, Lisa Unsworth (Eds) Food Ethics: Cash For Food: Freedom or dependency? Food Ethics Council Winter 2011 Volume 6 Issue 4 | www.foodethicscouncil.org

10. Drugmand Dana (2011) UN Food Expert Calls on South Africa to Create «Inclusive Food System». http://blogs.worldwatch.org/nourishingtheplanet/tag/un-special-rapporteur-onthe-right-to-food/. Accessed 16 April, 2013.

11. Drugmann D (2011)UN Food Expert Calls on South Africa to Create «Inclusive Food System»http://blogs.worldwatch.org/nourishingtheplanet/un-food-expert-calls-on-southafrica-to-create- $\%$ E2\%80\%9Cinclusive-food-system $\%$ E2\%80\%9D-agriculture-farmworkers-olivier-de-schutter-small-scale-farmers-south-africa/

12. Elizabeth A. Dowler, Deirdre O'Connor (2012) Rights-based approaches to addressing food poverty and food insecurity in Ireland and UK. Social Science and Medicine.74(2012)44-51

13. Falk G (n.d.) The Right to Food of Milk and Maize Farmers: Report of an investigative mission to Uganda.

14. FAO and UNHR (n.d) The right to Food. www.fao.org

15. FAO (2006). The Right to Food in Practice: Implementation at the National Level. Rome/ltaly

16. FAO (n.d) Right to Food Assessment: Philippines. FAO Publications, Rome.

17. FAO (n.d) The Right to Food. www.fao.org

18. Farrar Rebecca (2008). Exploring Human Rights implications Of Microfinance Initiatives. From the Selected Works of Rebecca Farrar.

19. Food and Agricultural Organization (FAO) (2010): Food and Agriculture Organization of the United Nations: Food Security Data and Definitions. ttp://www.fao.org/economic/ess/ess-fs/ess-fadata/en/\#access_food 
20. Getu, M.2001.Poverty Alleviation and Role of Microfinance in Africa: In Belshaw, D, Calderisi, R.Sugden, C (Eds), Faith in Development: Partnership between the World Bank and Churches of Africa, Regnum Books International, Oxford, UK

21. Hudon, M. (2007) Should Access to Credit Be A Right? CEB Working Paper No.07/008. Solvay Business School, Centre Emile Bernheim, Research Institute in Management Sciences.

22. International Institute for Environment and Development. 2012. Can small-scale farmers feed the world? Retrieved from: http://www.iied.org/can-small-scale-farmers-feed-world. Date 9 August, 2012.

23. Khandker $\mathrm{R}$ Shahidur. (1998): Fighting Poverty with Micro-credit: Experience in Bangladesh. USA: Oxford University, World Bank.

24. Lautze, S. and Hammock. (1996): Coping With Crisis: Coping with Aid. Medford, M.A. Feinstein International Famine Center, Tufts University.

25. Mago, S. (2010) Rural Microfinance and Poverty Alleviation in Zimbabwe: The Case of Masvingo District. Unpublished Ph.D Thesis. University of Fort Hare, South Africa.

26. Martins Deolinda and Yablonski Yenn (2011) New Solutions to Enduring Problems: Food Insecurity and Vulnerability in Sub-Saharan Africa. In Barling Liz, Dru Robin, Unsworth Lisa (Eds) Cask for Food: freedom or Dependency. Newman Thompson Limited. Food Ethics council. UK. Vol. 6 Issue 4.

27. Meinzen-Dick R. and M. Di Gregorio, (2004) Eds Collective Action and Property Rights for Sustainable Development: Focus II 2020 Vision. International Food Policy Research Institute(IFPRI)

28. Microcredit Summit E-News, Volume 5, No. 1, July 2007

29. Narayan Deepa (Ed). (2002): Empowerment and Poverty Reduction: A Sourcebook, The World Bank, Washington D.C., USA.

30. Olivier De Schutter (2010) Countries tackling hunger with a right to food approach: The United Nations Special Rapporteur On The Right To Food. Briefing Note 01 - May 2010

31. Pogge, T. (2002). World Poverty and Human Rights: Cosmopolitan Responsibilities and Reforms. Polity Press, Cambridge.

32. Rahim Aminur (2011).Rights to Food with a Human face in the Global South. Journal of Asian and African Studies, 46(3) 237-249.

33. Rawls John (1971/1999).A Theory of Justice. Harvard University Press: USA

34. Robinson, S. M. (2001): The Microfinance Revolution. Washington, D.C: The World Bank, Open Society Institute.

35. Schumacher E.F. (1973), "Small is Beautiful: A study of Economics as if People Mattered. London: Blond \& Briggs.

36. Sen, A. (1999) Development as freedom. New York, Alfred A. Knopf

37. Spivack Jameson. 2012. Olivier De Schutter Discusses the Right to Food and the Need to Unite Food Movements. http://blogs.worldwatch.org/nourishingtheplanet/olivier-deschutter-discusses-the-right-to-food-and-the-need-to-unite-food-movements-right-to-foodlocal-farmer-sustainable-agroecology-unite-movements/

38. Syngenta Foundation for Sustainable Agriculture.

39. United Nations Human Rights, 2010, The Right to Adequate Food, Fact Sheet 34. United Nations. Geneva.

40. United Nations' Committee on Economic, Social and Cultural Rights, 1999.Substantive Issues Arising in the Implementation of the International Covenant on Economic, Social and Cultural Rights. United Nations. Geneva.

$\begin{array}{lllllll}\text { 41. Western Nigeria Emir. J. Food Agric. 2007. } 19 & \text { (2): 38-47 }\end{array}$ http://www.cfa.uaeu.ac.ae/research/ejfa.htm 38

42. Yunus, M.: 2006, Nobel Prize Peace Prize Lecture 2006, The Nobel Foundation.

43. Yunus, M.: 2007, Remarks by Muhammad Yunus, Managing Director, Grameen Bank.

44. Zhou, Y (2010) Smallholder Agriculture, Sustainability and the Syngenta Foundation.

45. Ziegler, Jean (2006): «Economic, Social and Cultural Rights. The right to food». Report of the Special Rapporteur on the right to food, Mission to Guatemala. Economic and Social. 